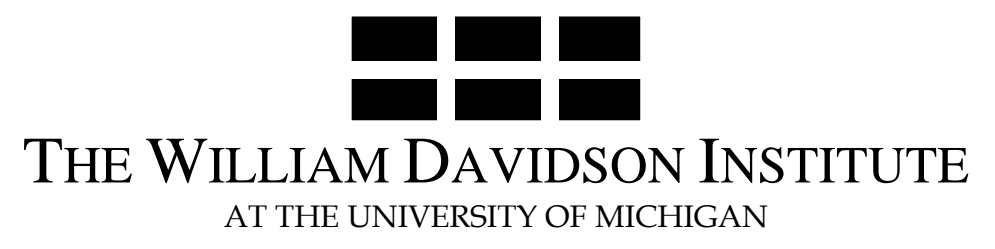

AT THE UNIVERSITY OF MICHIGAN

\title{
LABOUR MARKET REFORMS AND OUTCOMES IN ESTONIA
}

\author{
By: Zuzana Brixiova and Balázs Égert
}

William Davidson Institute Working Paper Number 1027

February 2012 


\title{
LABOUR MARKET REFORMS AND OUTCOMES IN ESTONIA ${ }^{1}$
}

\author{
Zuzana Brixiova ${ }^{\mathrm{a}}$ and Balázs Égert ${ }^{\mathrm{b}}$ \\ ${ }^{\text {a }}$ United Nations Development Programme Swaziland, Mbabane \\ ${ }^{\mathrm{b}}$ Organisation for Economic Cooperation and Development, Economics Department, Paris
}

\begin{abstract}
The unemployment rate in Estonia rose sharply in 2010 to one of the highest levels in the EU, after the country entered a severe recession in 2008. While the rate declined relatively rapidly in 2011, it remained high especially for the less educated. In 2009, the Employment Contract Law relaxed employment protection legislation and sought to raise income protection of the unemployed to facilitate transition from less to more productive jobs while mitigating social costs. Utilizing a search model, this paper shows that increasing further labour market flexibility through reducing the tax wedge on labour would facilitate the structural transformation and reduce the long-term unemployment rate. Linking increases in unemployment benefits to participation in job search or training programmes would improve the unemployed workers' incentives to search for jobs or retrain and the medium term labour market outcomes. Social protection schemes for the unemployed should be also strengthened as initially intended to give the unemployed sufficient time to search for adequate jobs or retrain for new opportunities.
\end{abstract}

JEL Classification: J08, J64, E24.

Keywords: Labour market reforms, search model, Estonia, OECD countries

\footnotetext{
${ }^{1}$ The authors thank Jan Svejnar, Andreas Wörgötter and participants at the $69^{\text {th }}$ IAES Conference (Prague) and the 2011 ACES/ASSA meetings (Denver) for helpful comments. We also thank Stefano Scarpetta for insightful suggestions on the first draft. The paper substantially expands the analysis from the 2009 OECD Survey of Estonia. Views expressed are those of the authors and do not necessarily reflect those of their institutions of affiliation.
} 


\section{Introduction}

Following a deterioration during the transition to a market economy and the Russian crisis in the 1990s, the labour market outcomes in Estonia improved markedly by the end of 2007. The employment rate exceeded the EU-15 average and participation rates increased. After entering a recession in 2008, Estonia's unemployment rate escalated from 4.1 percent in December 2007 to 19.8 percent in June 2010 - one of the highest levels in the European Union. Even though real GDP grew by almost 9 percent in 2011, unemployment remained about 13 percent. With high unemployment and the large share of low-value added non-tradable sectors including construction, a pressing issue for policymakers became reallocating workers across jobs and sectors to more productive activities, while mitigating fiscal and social costs. Flexibility of the labour market, together with job creation, became important for strong recovery and medium-term outcomes. ${ }^{1}$ At the same time, adequate social support for the unemployed was needed to ensure their minimum living standards and opportunities to improve livelihoods.

Applying the search frameworks of Mortensen and Pissarides (1999) and Van Ours (2007) to Estonia, this paper examines the impact of labour market reforms adopted in the country in 2009 and those expected in 2013, in particular deregulating employment protection and raising unemployment insurance. ${ }^{2}$ The analysis suggests that labour market adjustment from unemployment to increased high value-added activities would be eased if: (i) increases in unemployment benefits were made conditional on participation of the unemployed in active labour market programs, especially retraining and job search; (ii) the employers' social security contributions were reduced, and (iii) increases in minimum wages were contained. The reduction of labour taxation, especially for low-wage workers, could also stimulate job creation.

A simulation exercise based on the labour market matching model with active labour market policies of Van Ours (2007) illustrates that $i$ ) linking unemployment benefits to participation in active labour market programmes reduces unemployment if accompanied by effective job creation incentives; ii) in contrast, lowering minimum wages hampers incentives of the low-wage unemployed to search for jobs, but makes firms more willing to hire, with an ambiguous impact on the overall employment; iii) cuts in firms' social security contributions stimulate firms' incentives to hire.

The paper is organised as follows. Section 2 outlines the main features of the Estonian labour market, and Section 3 presents the search matching model and policy simulations. Section 4 compares the results for Estonia with some stylised facts for OECD countries, while Section 5 concludes.

\section{Main characteristics of the Estonian labour market}

From 2000 to early 2008, Estonia's labour market outcomes improved markedly: the unemployment rate dropped to close to 4 percent in 2008, its lowest point in 16 years, with long-term and very long-term unemployment rates also falling steadily (Figure1). At the same time, the employment rate and labour force participation increased. While aggregate outcomes improved, large inequalities persisted among regions, ethnic groups, and workers with different skill levels, with unemployment being particularly high among unskilled workers.

The economic boom, reflected also in eventual skill shortages, led to excessive real wage increases during 2005-07, both in the private and public sectors. Subsequently the gap between real wages and real GDP widened. After having risen sharply to 19.8 percent after Estonia fell into a deep recession in mid-2008, the

\footnotetext{
${ }^{1}$ The need for labour market flexibility is further underscored by the currency board arrangement.

2 In July 2009, the Employment Contracts Act became effective, which aimed at increasing the labor market flexibility by reducing costs of lay-offs and security through raising unemployment insurance. However, most of the measures aiming at raising security were postponed until 2013 (Leetmaa and Nurmela, 2011).
} 
unemployment rate has been declining and reached 13.3 percent in the third quarter of 2011. The structure of employment has also changed, with the share of workers on part-time and temporary contracts gradually rising since 2008 (Figure 1). Differences across skill levels remained: in Q2, 2010 unemployment rate was 32.7 percent for the uneducated population relative to the 18 percent overall rate (OECD, 2011).

Figure 1. Labour market indicators, Estonia, 2000-2011

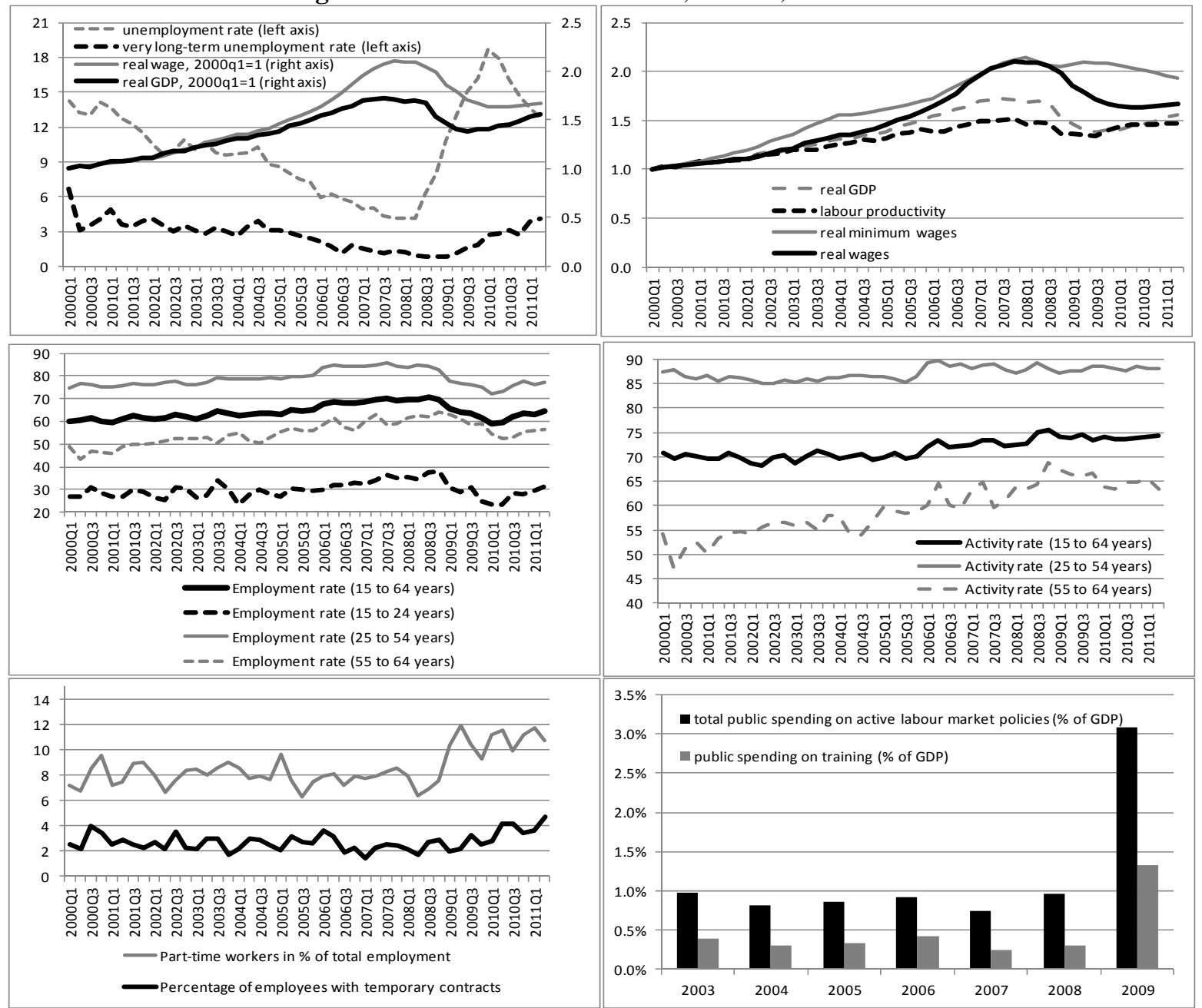

Source: Authors' calculations based on data drawn from Eurostat and OECD.

Note: Unemployment rate is calculated using Labour Force Survey data. Real wage is the nominal wage divided by the level of the consumer price index.

Besides high unemployment, especially among the less educated workers, the Estonian labour market has the following structural features.

First, it is characterised by a high degree of wage flexibility ${ }^{3}$ and almost fully decentralised wage setting, with wages being determined mostly within firms. Exceptions are the setting of the minimum wage, wages in the civil service sector set by government regulations, and wages in selected heavily unionized

\footnotetext{
${ }^{3}$ Flexibility reflects how quickly the labour markets adjust to shocks (Pissarides, 1997). Four elements are typically discussed: i) numerical flexibility, ii) working time; iii) functional flexibility, and iv) the rate at which nominal and real wages respond to changes in supply and demand (Eamets and Paas, 2007).
} 
industries (e.g., textiles). ${ }^{4}$ According to Rõõm (2008) and Maivali and Lubenets (2007), wage adjustments in Estonia are frequent, with substantial cyclical fluctuations and sizeable sectoral dispersion. Yet, wage flexibility declined during the boom period: while until 2004 wage increases reflected closely productivity gains (Babecký, 2008; Rõõm, 2008), during 2005-07 real wage increases were largely in excess of labour productivity growth due to labour and skill shortages resulting from rising demand ${ }^{5}$. At 20 and 40 percent respectively, Estonia's 2007 growth in average earnings (including bonuses and overtime) was among the highest and the increase of the civil sector wage was the highest in the EU (Figure 1).

According to a survey by Dabusinskas and Rõõm (2011), wages were downwardly flexible during the crisis especially relative to other European countries. Specifically, in summer 2009, around 46 percent of Estonian firms already cut wages of their workers and another 40 percent intended to do so. Overall, 30 percent of the labour force were impacted by wage cuts, a far larger share than in other countries surveyed.

Second, until 2009, Employment Protection Legislation (EPL) in Estonia was more rigid than in other Central European countries or the OECD average (Table 1). The rigidity stemmed from: regulation of regular contracts, notably from long notice periods for workers with short tenure; narrow definition of unfair dismissal; and the right to re-employment or high compensation for unfair dismissal. ${ }^{6}$ EPL was eased in 2009: the new Employment Contract Act deregulated comprehensively regular contracts, including i) a reduction in the notice period for redundancy to 15-90 working days, depending on the length of employment; ii) a cut in severance payments, costs of which are shared by the employer and the Unemployment Insurance Fund; and iii) an easing of dismissals and hiring, which facilitates overall mobility and job search of the new job market entrants (OECD, 2004). Estonia's EPL thus became slightly less stringent than in the euro area (Dabusinskas and Rõõm, 2011).

To address concerns about reduced employees' security due to a lighter EPL, the income protection for the unemployed was to be enhanced through raising the unemployment benefit replacement rate and easing the eligibility for unemployment insurance. Specifically, the unemployment income replacement rate was to be raised from 50 to 70 percent during the first 100 days of unemployment, and from 40 to 50 percent afterwards. Those leaving their jobs voluntarily were also to receive unemployment insurance benefits. However, adoption and implementation of these measures have been postponed to 2013 (Leetmaa and Nurmela, 2011).This delay is in contrast with measures of some other European countries that increased unemployment support to safeguard adequate living standards. ${ }^{7}$

Third, before the 2007-08 crisis, expenditures on active labour market policies (ALMPs), as a share of GDP, were very low in comparison to a European or OECD average. ALMPs thus played a minimal role in facilitating workers' employment. Incentives for unemployed workers to search or undergo training were also low. As shown in Figure 1, spending on ALMPs increased markedly to above 3 percent in 2009 from below 1 percent of GDP in 2008.

\footnotetext{
${ }^{4}$ Overall though, the rate unionization and the use of collective bargaining coverage in the private sector of the Estonian economy are very low (12 and 9 percent, respectively). Collective bargaining is almost irrelevant for the wage setting process in the overall economy (Dabusinskas and Rõõm, 2011).

${ }^{5}$ A key factor behind the wage flexibility was a widespread use of performance-related bonuses. The 2007 survey of private firms in industry, constructions, services, and trade revealed that about two thirds of firms use bonuses, and their share in the wage bills ranged from 14\% in industry to 23\% in trade (Dabusinskas and Rõõm, 2008).

${ }^{6}$ Yet, EPL regulations were not adhered to in practice (Eamets and Masso, 2005).

${ }^{7}$ As a response to the global crisis, several OECD countries extending the coverage (Sweden) or duration of their unemployment benefits (Portugal, United States).
} 
Fourth, the minimum wage, determined annually by agreement between trade unions and representatives of employers is low, measured by the ratio of the minimum wage to the average wage at around 30 percent. Yet it was increasing very rapidly until 2007. The increases in the minimum wage in these years exceeded both average real wage growth and labour productivity growth, thus pricing out of jobs low-income workers for whom the minimum wage may constitute a binding constraint. The minimum wage is determined annually at the centralised level and covers all employees. According to Rõõm (2008) and other estimates, approximately 6 percent of private sector workers in Estonia earned the minimum wage in 2008. But the influence of the minimum wage on wage formation goes beyond these six percent - for example, in some cases of unionized enterprises (e.g., textile), minimum wages constitute a basis from which wages of all workers are derived and stipulated in collective agreement.

Finally, Table 1 shows the very high tax wedge on labour, which stands in contrast to a modest overall tax burden on income tax and especially on capital gains: Overhead costs, comprising social contribution tax levied on employers accounted for almost 40 percent of wages in 2006 and remained at that level in 2011. The tax wedge is especially high when compared to OECD countries such as Ireland, the USA or the United Kingdom, whose labour markets are similar to Estonia’s (OECD, 2011).

Table 1. Main characteristics of the Estonian labour market in an international comparison

\begin{tabular}{l|c|cccc} 
& & Estonia & \multicolumn{4}{c}{ OECD } \\
& year & & AVERAGE & MAX & MIN \\
\hline EPL & 2008 & 2.1 & 1.94 & 3.72 & 0.21 \\
ALMP ( \%GDP) & 2007 & 0.1 & 0.41 & 1.02 & 0.05 \\
Minimum wage (\% average wage) & 2007 & 32 & 36.8 & 49.4 & 23.5 \\
Net replacement rate (short-term) & 2007 & 59 & 65.8 & 87.6 & 47.6 \\
Tax wedge (at 67\% of average worker earnings) & 2006 & 38.4 & 33.9 & 49.4 & 10.6 \\
Long-term unemployment (\% total) & 2007 & 52.8 & 28.9 & 72.3 & 0.7 \\
Temporary work contracts (\% total) & 2007 & 2.1 & 12.1 & 31.7 & 4.2 \\
\hline
\end{tabular}
Source: OECD and Eurostat.

\section{A matching model with active labour market policies: application to Estonia}

\section{1. $\quad$ The model}

To illustrate the likely medium-term outcomes of reforming labour market institutions, changes in active labour market programmes (ALMPs), unemployment benefits, minimum wages, and employers' social security contributions are examined in a standard search model, applied to Estonia. Specifically, the model outlined below is a somewhat modified version of Van Ours (2007), which extends the framework of Mortensen and Pissarides (1999) by adding participation in job search and/or training programmes. The application below focuses on the effect of labour market reforms on incentives for the unemployed to search for jobs or to participate in training programmes and for firms to create jobs.

In the model, workers can be either employed in the private sector or unemployed. Unemployed workers receive benefits $b$, value their leisure as $l$, and search for jobs or put effort in training with intensity $x \geq 0$ while incurring cost $k(x)=\frac{x^{2}}{2 \gamma}$, where $\gamma>0$. Employed workers receive wage $w$. Firms post vacancies to fill jobs at cost $c$. Each filled job results in output $y$, with $y>w$. The key component of the model is a matching function $A=A(x u)^{1-\eta} v^{\eta}$, where $A>0$ denotes the efficiency of the matching and $\eta \in(0,1)$ is the elasticity of matches with respect to vacancies. The workers' search/training effort results in job offers, 
which arrive at rate $\mu(\theta) x=A \theta^{\eta}$, where $\theta=\frac{v}{x u}$ denotes the ratio of vacancy rate, $v$, to effective unemployment rate, $x u$, i.e. it describes the tightness of the labour market from firms' perspective. Conversely, firms fill their vacancies at rate $\frac{\mu(\theta)}{\theta}=A \theta^{\eta-1}$. All job matches dissolve at rate $\delta$, and firms pay to each laid-off worker a severance payment $K$. The employment rate, $e$, and unemployment rate, $u$, change according to:

$$
\begin{aligned}
& \dot{e}=A \theta^{\eta-1} v-\delta e \\
& \dot{u}=\delta e-A \theta^{\eta} x u
\end{aligned}
$$

With normalizing the labour force to 1 , that is $1=e+u$, the steady state equilibrium unemployment decreases with search/training effort and the tightness of the labour market:

$$
\bar{u}=\frac{\delta}{\delta+A \bar{\theta}^{\eta} \bar{x}}
$$

To illustrate the impact of mandatory participation in ALMPs on workers' search/training effort, a scenario where all unemployed workers can receive unemployment benefit only if they participate in the job search assistance or retraining programme is considered. Participation in such programme lowers the value of leisure for the unemployed by fraction $z \in(0,1)$ and their search cost by a fraction $\sigma \in(0,1)$. Workers accept jobs only when the value of employment, $V_{E}$, exceeds the value on unemployment, $V_{U}$ :

$$
\begin{aligned}
& \rho V_{U}=\max _{x}\left(b+(1-z) l-\frac{(1-\sigma) x^{2}}{2 \gamma}+A \theta^{\eta} x\left(V_{E}-V_{U}\right)\right) \\
& \rho V_{E}=w+\delta\left(V_{U}-V_{E}\right)
\end{aligned}
$$

where $\rho$ is the discount rate. Denoting $J_{E}$ as value of filled job and $J_{V}$ as value of vacancy, the corresponding Bellman equations are:

$$
\begin{aligned}
& \rho J_{E}=y-(1+\tau) w+\delta\left(J_{V}-J_{E}-K\right) \\
& \rho J_{V}=-C+A \theta^{\eta-1}\left(J_{E}-J_{V}\right)
\end{aligned}
$$

Where $y$ is the output from the filled vacancy, $w \tau$ is the social employers' contribution tax paid, and $K$ is the severance cost incurred by the firm. Under the standard assumption of free entry into the job creation, value of posting a vacancy is $J_{v}=0$. (6) and (7) can therefore be reduced to:

$$
\frac{y-(1+\tau) w-\delta K}{\rho+\delta}=\frac{c \theta^{1-\eta}}{A}
$$

The optimal search/training intensity $x$ can be derived directly from (4): 


$$
\bar{x}=\frac{\gamma}{(1-\sigma)} A \theta^{\eta}\left(V_{E}-V_{U}\right)
$$

The search/training effort rises with higher loss of leisure due to participation in the ALMP programme.

To complete the characterization of unemployment outlined in (3), a solution for the tightness of the labour market, $\theta$, needs to be obtained through deriving wages. Regarding wage determination, the model deviates from the standard assumption of Nash wage bargaining. Instead, it assumes that flexible wages move with productivity changes: $w=\phi y$, where $\phi \in(0,1)$, consistent with the empirical evidence (Dabusinskas and Rõõm, 2011; Babecký, 2008; and Rõõm, 2008).

\section{2. $\quad$ Comparative statics}

The comparative statics relevant in the Estonian context are:

Table 2. Comparative statics in the job search-matching model

\begin{tabular}{lcc}
\hline \multicolumn{1}{c}{ Effect of an increase in: } & $\begin{array}{c}\text { On search effort of the } \\
\text { unemployed } x\end{array}$ & $\begin{array}{c}\text { On unemployment } \\
\text { rate } u\end{array}$ \\
\cline { 2 - 3 } Reduced utility from less leisure z & + & - \\
Search cost reduction $\sigma$ & + & - \\
Matching efficiency $A$ & + & + \\
Minimum wage $w^{\text {min }}>\phi y$ & + & + \\
Unemployment benefit $b$ & - & + \\
Payroll tax $\tau$ & - & + \\
Separation rate $\delta$ & - &
\end{tabular}

The search/training effort of the unemployed rises with effective job search and training programmes, lower search/training cost, improved matching efficiency, and reduced separation rate. The ALMPs can improve matching efficiency (by dissemination of information) as well as reduce search/training cost and separation rate.

\subsection{Simulation results}

The model is simulated using quarterly parameters from existing studies and the Estonian labour market data. Parameters are specified as follows: 
Table 3. Parameters of the model

\begin{tabular}{|c|c|c|c|}
\hline Parameter & Definition & Value & Source \\
\hline$y$ & Output (productivity) & 1 & Van Ours (2007) \\
\hline$\delta$ & Separation rate (quarterly) & 0.045 & Statistics Estonia \\
\hline$\tau$ & $\begin{array}{l}\text { Social security contribution } \\
\text { (\% of wage) }\end{array}$ & 0.33 & Ministry of Finance, the Republic of Estonia \\
\hline$C$ & Cost of posting vacancies & 6 & $\begin{array}{l}\text { Set so that vacancy-unemployment ratio corresponds to } \\
\text { the steady state value of } 0.8 \text { (based on past outcomes) }\end{array}$ \\
\hline$\eta$ & $\begin{array}{l}\text { Elasticity of matching to } \\
\text { Vacancies }\end{array}$ & 0.5 & Van Ours (2007) \\
\hline$\rho$ & Discount rate & 0.025 & Van Ours (2007) \\
\hline A & $\begin{array}{l}\text { Efficiency of matching } \\
\text { Function }\end{array}$ & 1 & Van Ours (2007) \\
\hline $\mathrm{b}$ & $\begin{array}{l}\text { Unemployment benefit, } \\
\text { Including value of leisure }\end{array}$ & 0.4 & Shimer (2005) \\
\hline$b_{u}$ & Replacement rate (part of b) & 0.25 & Set at the current rate of $50 \%$ \\
\hline$\gamma$ & Cost of job search & 0.9 & Set to obtain steady state unemployment of $6.5 \%$ \\
\hline$\phi$ & Share of wage in output & 0.5 & Share of compensation of employees in GDP \\
\hline
\end{tabular}

Figures below illustrate that participation in active labour market programmes, especially job search activation or training programmes, would increase workers search or training efforts through two channels: 1) by reducing the value of leisure and hence increasing relative payoffs from working; and 2) by increasing workers' chance of exiting unemployment. As a result of workers' increased search or training effort, unemployment would decline through both channels. Regarding effective application, programmes encouraging job search would help speed up recovery from cyclical unemployment where new jobs are created in the same sectors and hence workers can draw on existing skill. In contrast, training programmes would typically facilitate structural change, where new jobs are created in new sectors (for example in services rather than construction). ${ }^{8}$

Figure 2. Impact of mandatory participation in ALMPs on search and unemployment ${ }^{9}$

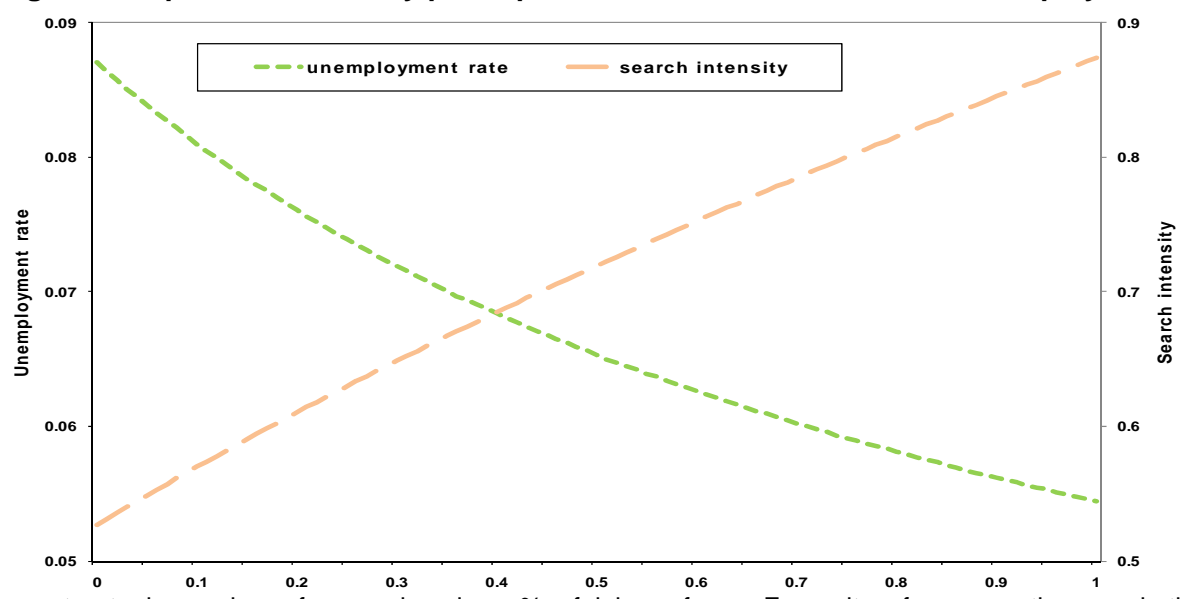

Note: Unemployment rate is number of unemployed as \% of labour force. For units of consumption good, the price of the consumption good is normalised to one. Mandatory participation represents foregone leisure.

\footnotetext{
${ }^{8}$ Training programs can also help the unemployed workers maintain or improve the existing skills.

${ }^{9}$ All simulations (Figure $2-5$ ) focus on the impact of labour market policies on search effort, that is participation in job search programs. Results apply to participation in training programs as well.
} 
Figure 3. Impact of search cost cuts on search and unemployment

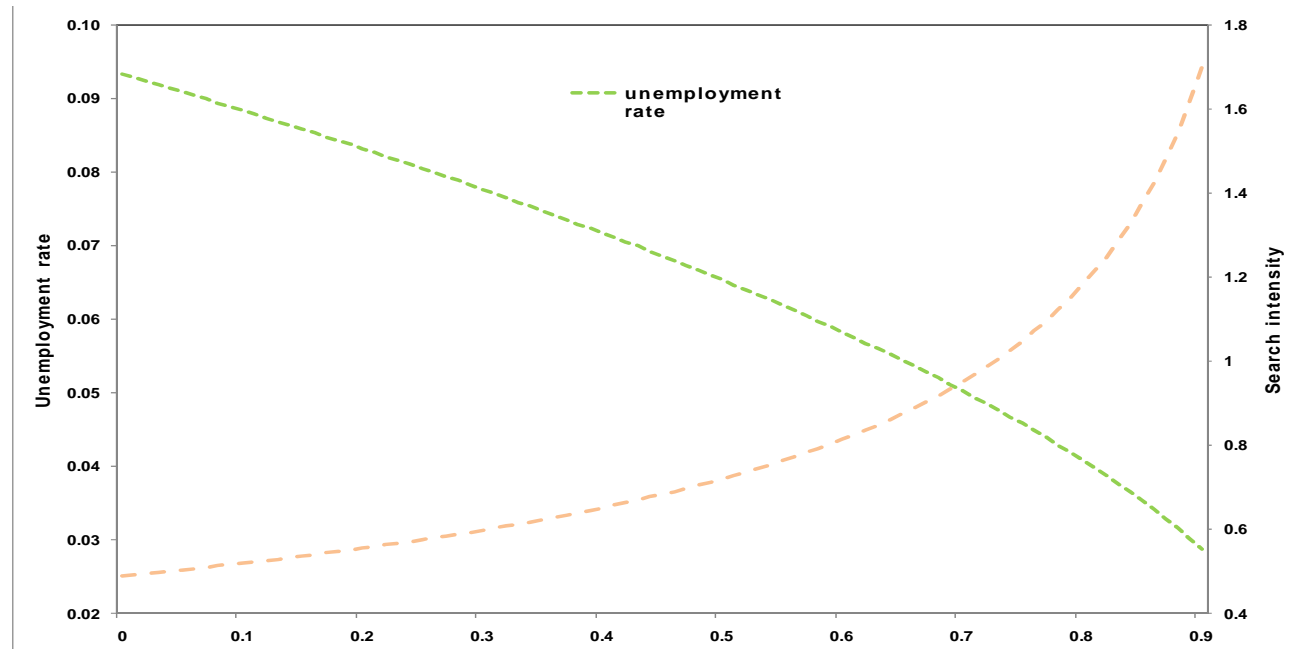

Note: Unemployment rate is number of unemployed as \% of labour force. For units of consumption good, the price of the consumption good is normalised to one.

Source: Author's calculations.

Figure 4. Impact of minimum wage increase on search, unemployment and vacancies

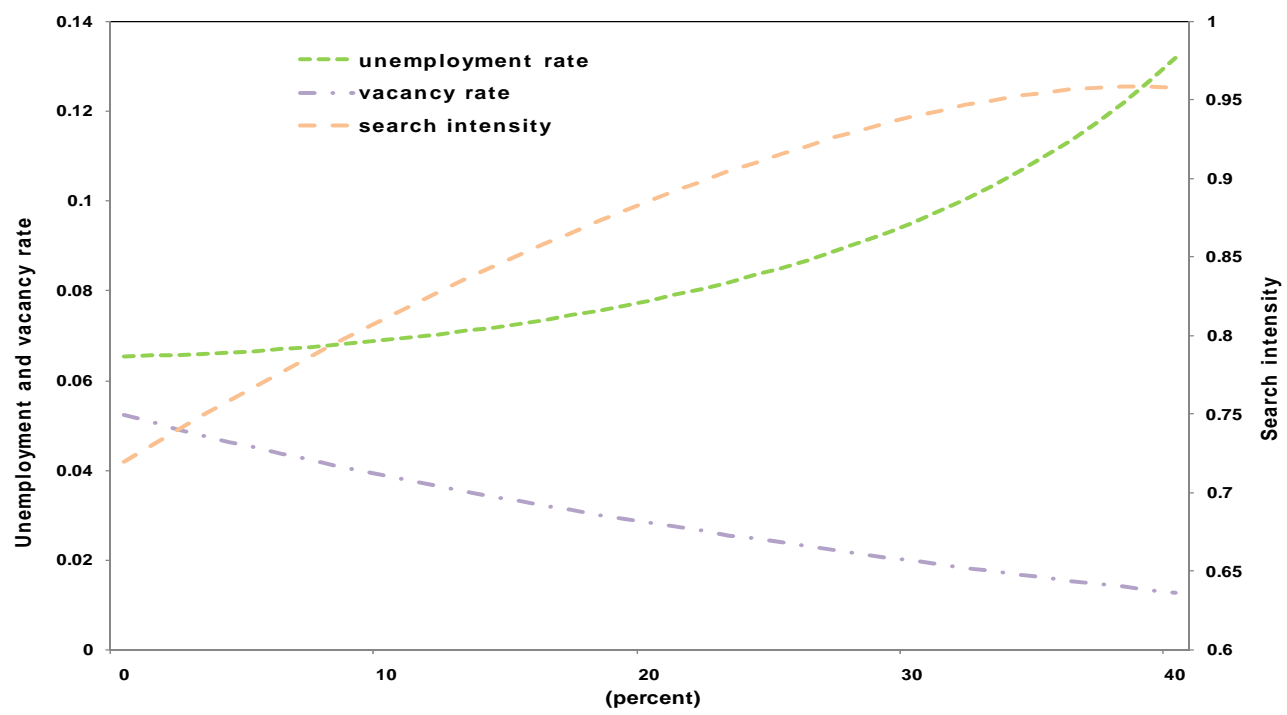

Note: Unemployment and vacancy rates are respectively the number of unemployed and vacancies as $\%$ of labour force. For units of consumption good, the price of the consumption good is normalised to one.

Source: Author's calculations. 
Figure 5. Impact of social security tax on vacancies and unemployment

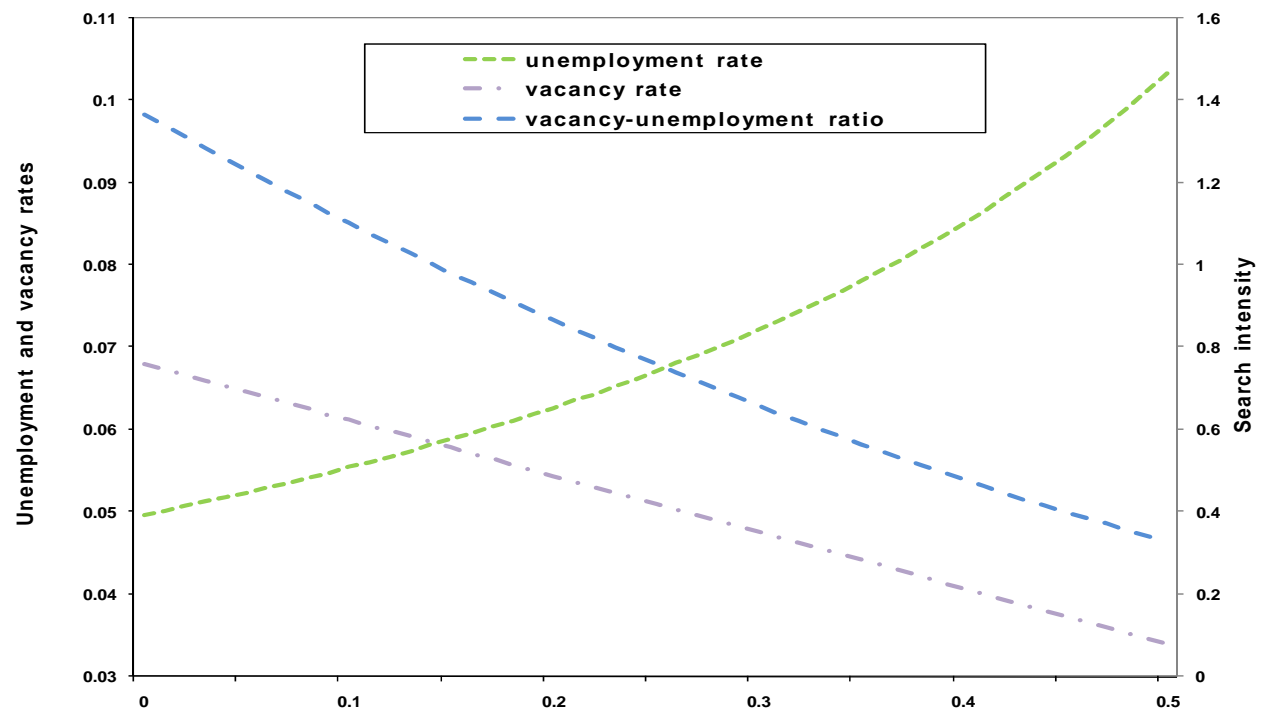

Note: Unemployment and vacancy rates are respectively the number of unemployed and vacancies as \% of labour force. The vacancy/unemployment ratio is the vacancy rate divided by the unemployment rate.

Source: Author's calculations.

Figure 4 illustrates the impact of increases in minimum wages on the low-wage unemployed workers for whom these wages may constitute a binding constraint. While workers would increase their search/training effort because of a higher payoff from working, the positive impact could be more than offset by firms' posting fewer vacancies because of lower profits. Figure 5 illustrates the likely impact of cuts in social contribution tax paid by employers. The direct consequence would be a higher profitability of firms and hence more vacancies/lower unemployment rate, provided that the lost revenues are replaced by less distortionary taxes.

\subsection{Policy lessons}

The above simulation exercise helps us draw several policy conclusions:

- Linking increases in unemployment benefits to participation in job search or training programmes would improve workers' incentives to search for jobs or put effort into training, by reducing the value of being unemployed and improving their chances of finding a job.

- While lower minimum wages would somewhat hamper incentives of the low-wage unemployed to search for jobs or be retrained, firms would be more willing to hire. The unemployment rate could decline as long as the prevailing minimum wage level is binding.

- A lower tax wedge due to cuts in firms' social security contributions would raise firms' payoff from filled jobs, and hence their incentives to post vacancies. Search or training effort of workers would also increase, as their chances of finding jobs would improve. Both the unemployment level and duration would decline. 


\subsection{The transition costs}

Although the results presented in the previous section focus on the longer term labour market outcomes, the above measures would also affect the speed of adjustment and the associated transition costs, and hence the political support for reforms. Generally, the speed of adjustment is faster when labour market flexibility is enhanced, underlying for example the importance of reducing the social security tax, especially on low income workers, as a way to ease the recovery and reduce medium term unemployment.

Mourougane and Vogel (2008), who examined the length of adjustments to selected structural reforms in the OECD countries, found that the impact of structural reforms takes several years. As reallocating resources (e.g., labour) is costly, the efficiency gains take time to materialize. Effective monetary policy and well functioning financial markets can reduce the adjustment speed and transition cost through, for example, facilitating the access of new firms to credit. According to the authors, the tax wedge on labour, unemployment replacement ratio, and product market regulations play a major role in explaining the evolution of structural unemployment in OECD countries during 1983-2003. Tax wedge and product market regulations also have the largest impact in the short run. The importance of easing employment protection is in accordance with results of Caballero et al. (2004), who found that in countries with strong law enforcement, increasing job security would reduce the annual speed of adjustment to shocks by a third, while subtracting $1 \%$ from productivity growth.

While our model illustrations focus on the flexibility aspects of labour market reforms, the experience of other countries from the crisis and other episodes shows that the importance establishing adequate social protection mechanisms that would also help the unemployed search for appropriate jobs or retrain cannot be overstated. Putting differently, too low level of protection may force the unemployed to accept jobs that are not 'good' matches and hence increase the job dissolution rate and transaction costs associated with the job matching process.

\section{Confronting the results with stylised facts from OECD countries}

This section seeks to summarise available evidence from OECD countries regarding the impact of labour market reforms aimed to increase flexibility on the level of unemployment. Measures considered are: i.) ALMPs; ii.) the minimum wage; and iii.) the tax wedge.

\subsection{Active labour market policies and unemployment}

Over the medium term, increases in ALMPs would enhance workers' employability and give a larger role to automatic stabilisers. Among various activation approaches, job search assistance or "work first" strategies tend to have a large positive impact and low cost. Long term labour market programmes alone, such as training, often have no or even a negative impact in the short term, but increase employment and earnings $2-3$ years after the individuals completed them. Hence mixed strategies combining job search and selective training programme participation seem to be most effective (OECD, 2005a,b).

Well designed and targeted activation policies or training programmes can offset the disincentives due to generous unemployment benefits. For instance, the Danish Flexicurity model, which is based on low employment protection, high expenditures on active labour market policies and generous unemployment benefits conditional on the obligation to take on job offers seems to incentivise firms to create jobs and unemployed persons to take up new job offers. Figure 6 below shows that the combination of extensive ALMP with higher net replacement rates and lower employment protection legislation might go in tandem with lower unemployment rates in OECD countries. 
Figure 6. The combination of ALMP, EPL and generous contributions and unemployment rate in OECD countries

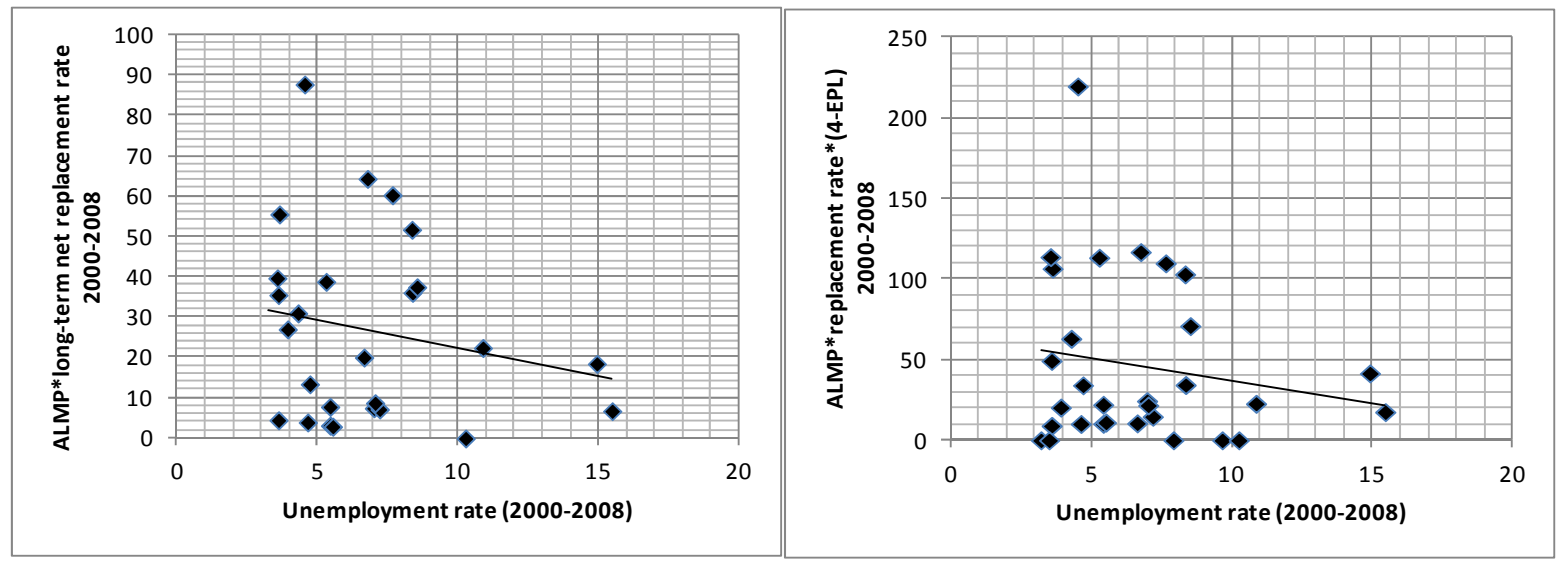

Source: Authors' calculations using data obtained from the OECD

Note: Vertical axis of the left panel shows an indicator, which is the product of public expenditures on ALMPs as a share of GDP and the long-term net replacement rate of unemployed persons, both measures averages of the period 2000 to 2008. Vertical axis of the right panel is augmented by the effect of the inverted employment protection legislation indicator (EPL). EPL ranges from 1 (least restrictive) to 4 (most restrictive). Hence, a low EPL would increase the overall value of the product of the three subindicators, while a high EPL would lower it. The unemployment rate is the period average for 2000-08.

The experience of OECD countries suggests that Estonia could improve the effectiveness of its ALMPs at a given level of expenditures by linking increases in unemployment benefits to participation in ALMP programmes and monitoring performance of the employment offices. Increases of unemployment benefits and their duration should be conditional on work availability and active job search and/or participation in job creating or training programmes (OECD, 2006). To raise ALMP's effectiveness, efficiency of employment services could also increase. Regarding benefit conditionality, Estonia could introduce practices of some of the OECD members:

- Required frequency of reporting of search activities could be raised from monthly to every two weeks, as is done, for example, in Australia, the Czech Republic, United Kingdom, and the United States. Personal visits seem most effective (OECD, 2007).

- Increases in benefit entitlements should be conditional on participation in ALMPs programmes, such as job creation (entrepreneurship) or training. Similar links have been established in Australia (Mutual obligation strategy); the UK (New Deal strategy) and other European countries (Grubb, Singh and Tergeist, 2009).

\subsection{Minimum wage, tax wedge and unemployment}

A prevailing view in the economic profession is that a high tax wedge could lead to an insufficient creation of firms and jobs, and constitutes a particularly strong impediment for SMEs. Panel A of Figure 7 shows that a higher tax wedge goes hand in hand with higher unemployment rates in OECD countries. In the case of Estonia, surveys conducted by the Estonian Research Institute indicate that high taxes on labour are the main reason for undeclared work (Leetmaa and Vork, 2007). Against this backdrop, one of the proposals of the employers' representatives is to shift the burden of taxation from employers towards workers, by splitting the contribution between these two parties (Employers' Manifesto for 2007 - 2011).

High tax wedges are particularly detrimental to employment in countries with high minimum wages, because the tax burden cannot be passed on to workers (Bassanini and Duval, 2006). In fact, data shown in Panel A of Figure 7 that a higher tax wedge is associated with a higher unemployment rate in OECD 
countries over the period 2000 to 2008. In addition, a positive correlation exists between the product of the tax wedge and the minimum wage (as a share of average earnings), on the one hand, and the unemployment rate, on the other, implying that a higher tax wedge coupled with a higher minimum wage is linked to a higher unemployment rate in OECD countries.

In the Estonian context this provides additional reasons (besides macroeconomic and inflationary considerations) why minimum wage increases should be kept in line with productivity growth and at a level which does not reduce employment options of low-productivity workers. Estonia could include an independent committee of outside experts in negotiations, also to bring the macroeconomic perspective, as was done, for example, in Ireland, the United Kingdom, and Australia. In addition, the employers' social security contribution should be reduced, especially given the high tax wedge on low-income workers, as was recently done, for example in the Czech Republic in the context of the economic crisis.

More general policies may also influence labour market outcomes. A business-friendly environment that promotes the creation of firms and allows for more flexibility in adjusting to shocks is likely to reduce the unemployment rate. Panel B of Figure 7 shows a positive correlation between product market regulations (PMR) and unemployment rate in OECD countries: a lower degree of regulation is associated with a lower unemployment rate. A better educated labour force is also essential to reduce frictions in matching job offers with job seekers. An increased ability to learn and think independently at the age of 15, captured by the PISA scores, tends to be associated with lower unemployment rates in OECD countries (Panel B of Figure 2). More broadly, and as shown in the above model, adult learning, in particular well targeted training programmes to close skill gaps in selected areas, can also help align workers' skills with demands of the labour market.

Figure 7. Policies and the unemployment rate in OECD countries Panel A. Tax wedge, minimum wages and the unemployment rate

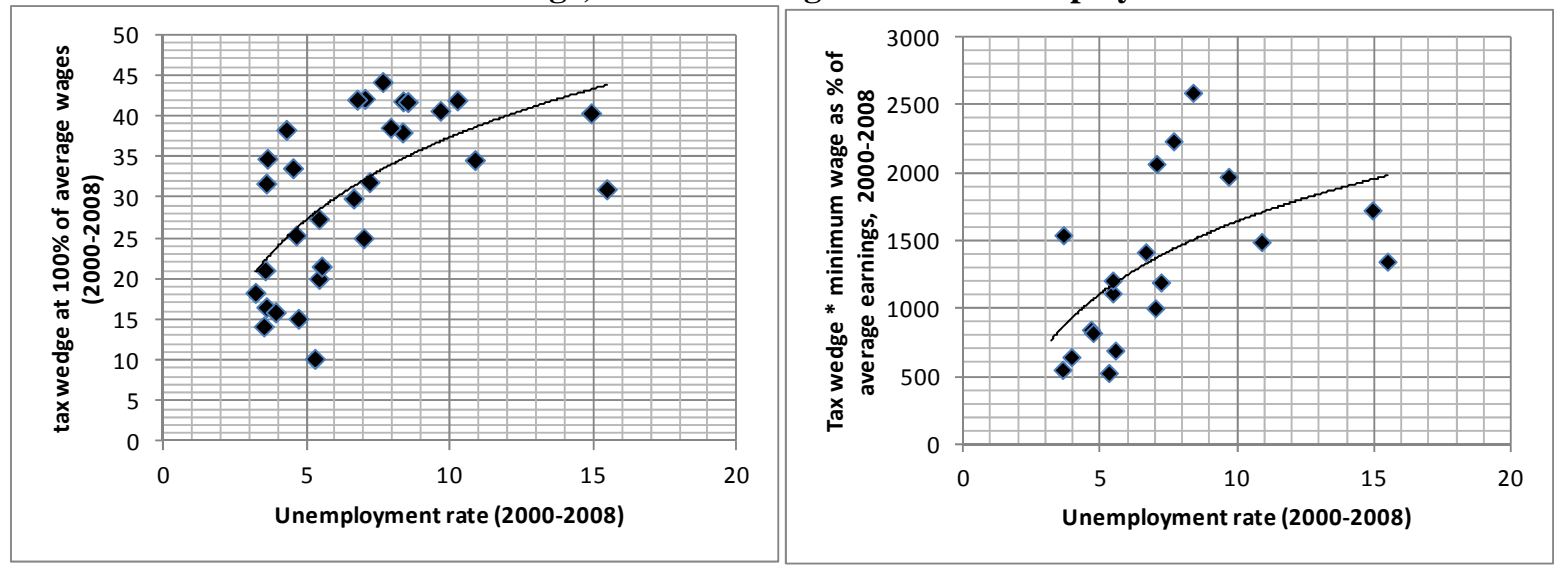


Panel B. Product market regulation, PISA scores and the unemployment rate

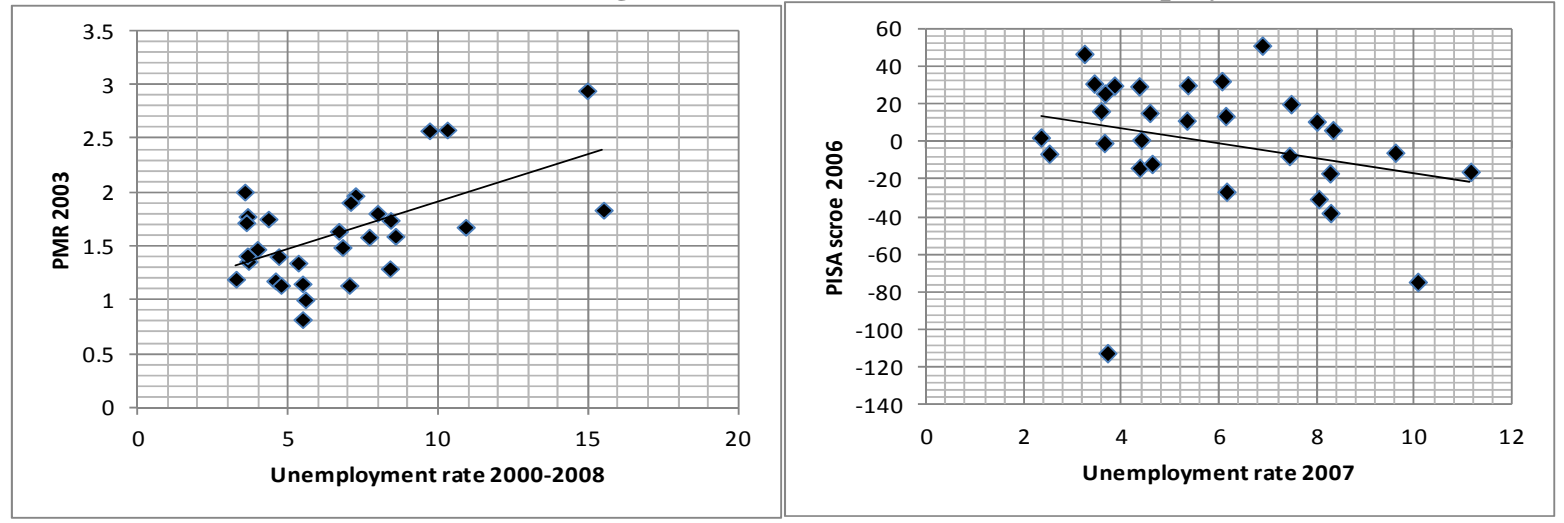

Source: authors’ calculations using data obtained from the OECD

Note: Vertical axis of the left panel of Panel A shows the tax wedge at $100 \%$ of average wages for 2000-08. The right panel of panel A shows an indicator which is calculated at the tax wedge multiplied by the minimum wage as a share of average earnings over the period 2000-08. Vertical axis of panel B depicts the 2003 vintage of product market regulation (PMR) and the 2006 PISA scores. The unemployment rate is the period average for 2000-08.

\section{Conclusions}

Following years of steady decline during 2001-2007, the unemployment rate in Estonia increased dramatically from 4.1 percent in December 2007 to 19.8 percent in June 2010 after the country entered a severe recession in 2008. While the rate was already down to 13.3 percent in September 2011, it remains high, especially among the less educated segments of the population. In this paper we examined labour market institutions and policies that may help Estonia reach better longer term labour market outcomes become.

While the Estonian labour market had been already flexible in many ways, the Employment Protection Legislation adopted in 2009 removed some of the remaining rigidities that hampered hiring of new workers, especially first entrants to the job market. It also eased transition from less to more productive activities, which is consistent with Estonia's objective to become a knowledge-based economy. The Estonian labour markets would also benefit from reduction of high tax wedge on wages as well as from keeping increases of the minimum wage in line with changes in labour productivity.

Results of a simulated search-matching model suggest that Estonia could adopt several measures to increase flexibility of its labour market and thus ease the recovery and improve medium term outcomes. These measures include strengthening incentives of the unemployed workers to search for jobs or participate in training and job search programmes and incentives for firms to create job creation such as: (1) implementing fully the reduced lay-off notice periods and severance payments, as stipulated in the Employment Contract Act; (2) making increases in unemployment benefits conditional on active job search and retraining; and (3) reducing the tax wedge by cutting social security contributions of employers, especially on low-wage workers. The Estonian labour market would also benefit from improving employment incentives for low wage workers, such as reducing social security contributions of employers on low wage workers, as adopted, for example, in the Czech Republic as part of the anti-crisis package.

While not addressed in this paper, the experience of other countries shows that adequate social protection mechanisms would also improve longer term labour outcomes by allowing the unemployed to search for appropriate jobs or retrain for new jobs arising from structural changes in the economy. We leave this important topic for further research. 


\section{BIBLIOGRAPHY}

Babecký, J. (2008), “Aggregate wage flexibility in the new EU member States”, AUCO Czech Economic Review 2, Vol. 2, pp. 123-145.

Bassanini, A. and R. Duval (2006), "Employment patterns in OECD countries: reassessing the role of policies and institutions, Social, Employment and Migration Working Papers, No. 35, OECD, Paris.

Caballero et al. (2004), "Effective labour regulation and microeconomic flexibility”, Federal Reserve Bank of Boston Working Papers, No. 04-06.

Dabusinskas, A. and T. Rõõm (2011), "Survey evidence on wage and price setting in Estonia”, Bank of Estonia Working Paper 6/2011.

Eamets, R. and T. Paas (2007), "Labour market flexibility and flexicurity”, in Paas and Eamets (eds.), Labour Market Flexibility, Flexicurity, and Employment: Lessons of the Baltic States, pp. 41-60.

Eamets, R. and J. Masso, (2005), "Paradox of the Baltic States: labour market flexibility but protected workers?”, European Journal of Industrial Relations, Vol. 11, No. 1, pp. 71-90.

Grubb, D., S. Singh and P. Tergeist (2009), “Activation policies in Ireland”, OECD Social, Employment, and Migration Working Papers, No. 75.

Leetmaa, R. And K. Nurmela (2011), 'EEO Review: Adapting unemployment benefit systems to the economic cycle, 2011 - Estonia', PRAXIS Centre for Policy Studies.

Leetmaa, R. and A. Vork (2007), “Article on undeclared work from SYSDEM correspondent: Estonia”, European Employment Observatory, May.

Maivali and Lubenets (2007) Managed vs. Free Wage-Setting in Finland and Estonia: Optimizing Outcomes, ECOFIN Country Notes, Volume IV, Issue 10.

Mortensen, D. and C. Pissarides (1999), "New developments in models of search in the labour market”, in Ashenfelter, O. and D. Card (eds.), Handbook of Labour Economics, Vol. 3, pp. 2567-2627, North-Holland, Amsterdam.

Mourougane, A. and L. Vogel (2008), "Speed of adjustment to selected labour market and tax reforms", OECD Economics Department Working Papers, No. 647.

OECD (2011), OECD Economic Surveys - Estonia, OECD, Paris.

OECD (2009), OECD Economic Surveys - Estonia, OECD, Paris.

OECD (2007; 2006; 2005a; 2004), OECD Employment Outlook, various issues, OECD, Paris.

OECD, 2005b, Promoting Adult Learning, OECD, Paris.

Van Ours, J. (2007), “Compulsion in active labour market programmes”, National Institute Economic Review, No. 202, pp. 67-78, October. 
Pissarides, C. (1997), "The need for labour market flexibility in a European economic and monetary union”, Swedish Economic Policy Review, No. 4, 513-546.

Rõõm, T. (2008), “The principles of wage formation in Estonian companies”, Bank of Estonia, draft.

Shimer, R. (2005), “The cyclical behaviour of equilibrium unemployment and vacancies”, American Economic Review, 95 pp. 24-49, March. 


\section{DAVIDSON INSTITUTE WORKING PAPER SERIES - Most Recent Papers}

The entire Working Paper Series may be downloaded free of charge at: www.wdi.umich.edu

CURRENT AS OF 2/7/12

\begin{tabular}{|c|c|c|}
\hline Publication & Authors & Date \\
\hline NO. 1027: LABOUR MARKET REFORMS AND OUTCOMES IN ESTONIA & Zuzana Brixiova and Balazs Egert & Feb 2012 \\
\hline $\begin{array}{l}\text { No. 1026: The Impact Of Capital Measurement Error Correction On } \\
\text { Firm-Level Production Function Estimation }\end{array}$ & Lubomir Lizal \& Kamil Galuscak & Jan 2012 \\
\hline $\begin{array}{l}\text { No. 1025: CREDIT CONSTRAINTS AND PRODUCTIVE ENTREPRENEURSHIP IN } \\
\text { AFRICA }\end{array}$ & $\begin{array}{l}\text { Mina Baliamoune-Lutz, Zuzana } \\
\text { Brixiová \& Léonce Ndikumana }\end{array}$ & Dec 2011 \\
\hline No. 1024: Entry Costs and Increasing Trade & $\begin{array}{l}\text { William F. Lincoln and } \\
\text { Andrew McCallum }\end{array}$ & Nov 2011 \\
\hline $\begin{array}{l}\text { No. 1023: The Dependence Of CEECs On Foreign Bank Claims: Direct } \\
\text { And Indirect Risks Of Capital Withdrawal }\end{array}$ & $\begin{array}{c}\text { Sophie Brana and } \\
\text { Delphine Lahet }\end{array}$ & Nov 2011 \\
\hline $\begin{array}{l}\text { No.1022: The Development Effects Of Natural Resources: } \\
\text { A Geographical Dimension }\end{array}$ & $\begin{array}{l}\text { Fabrizio Carmignani \& } \\
\text { Abdur Chowdhury }\end{array}$ & Nov 2011 \\
\hline $\begin{array}{l}\text { No. 1021: How to Stir Up FDI Spillovers: Evidence from a Large Meta- } \\
\text { Analysis }\end{array}$ & Tomas Havranek \& Zuzana Irsova & Nov 2011 \\
\hline $\begin{array}{l}\text { No. 1020: Volatility transmission in emerging European foreign exchange } \\
\text { markets }\end{array}$ & $\begin{array}{c}\text { Evzen Kocenda, Vit Bubak \& } \\
\text { Filip Zikes }\end{array}$ & July 2011 \\
\hline $\begin{array}{l}\text { No. 1019: Whither human capital? The woeful tale of transition to tertiary } \\
\text { education in India }\end{array}$ & $\begin{array}{l}\text { Sumon Bhaumik and } \\
\text { Manisha Chakrabarty }\end{array}$ & July 2011 \\
\hline $\begin{array}{l}\text { No. 1018: From Prosperity to Depression: Bulgaria and Romania } \\
(1996 / 97-2010)\end{array}$ & $\begin{array}{l}\text { Nikolay Nenovsky, Kiril Tochkov } \\
\text { and Camelia Turcu }\end{array}$ & May 2011 \\
\hline $\begin{array}{l}\text { No. 1017: Institutions, Governance and Technology catch-up in North } \\
\text { Africa }\end{array}$ & Imed Drine & May 2011 \\
\hline No. 1016: Financial Efficiency and the Ownership of Czech Firms & $\begin{array}{l}\text { Evzen Kocenda, Jan Hanousek } \\
\text { and Michal Masika }\end{array}$ & May 2011 \\
\hline $\begin{array}{l}\text { No. 1015: Default Predictors in Retail Credit Scoring: Evidence from } \\
\text { Czech Banking Data }\end{array}$ & Evzen Kocenda \& Martin Vojtek & April 2011 \\
\hline $\begin{array}{l}\text { No. 1014: Exchange Rate Pass-Through in Transition Economies: The } \\
\text { Case of Republic of Macedonia }\end{array}$ & Besnik Fetai & April 2011 \\
\hline $\begin{array}{l}\text { No. 1013: Establishing Data Collection Procedures Equivalence in } \\
\text { International Business Research }\end{array}$ & $\begin{array}{l}\text { Agnieszka Chidlow \& } \\
\text { Pervez N. Ghauri }\end{array}$ & $\begin{array}{l}\text { March } \\
2011\end{array}$ \\
\hline $\begin{array}{l}\text { No. 1012: The Link between Innovation and Productivity in Estonia's } \\
\text { Service Sectors }\end{array}$ & Priit Vahter \& Jaan Masso & $\begin{array}{c}\text { March } \\
2011\end{array}$ \\
\hline $\begin{array}{l}\text { No. 1011: Learning by exporting: evidence based on data of knowledge } \\
\text { flows from innovation surveys in Estonia }\end{array}$ & Priit Vahter & Feb 2011 \\
\hline $\begin{array}{l}\text { No. 1010: Firm Investment \& Credit Constraints in India, } 1997 \text { - 2006: } \\
\text { A stochastic frontier approach }\end{array}$ & $\begin{array}{l}\text { Sumon Bhaumik, Pranab Kumar } \\
\text { Das and Subal C. Kumbhakar }\end{array}$ & $\operatorname{Jan} 2011$ \\
\hline No. 1009: Industrial Enlargement And Competitiveness Index & Art Kovacic & Jan 2011 \\
\hline $\begin{array}{l}\text { NO. 1008: SUPPORTING AFRICA'S POST-CRISIS GROWTH: THE ROLE OF } \\
\text { MACROECONOMIC POLICIES }\end{array}$ & $\begin{array}{c}\text { Zuzana Brixiova, Leonce } \\
\text { Ndikumana \& Kaouther } \\
\text { Abderrahim }\end{array}$ & Jan 2011 \\
\hline $\begin{array}{l}\text { No. 1007: The Funding \& Efficiency of Higher Education in Croatia \& } \\
\text { Slovenia: A Non-Parametric Comparison w/ the EU \& OECD Countries. }\end{array}$ & $\begin{array}{l}\text { Aleksander Aristovnik and } \\
\text { Alka Obadic }\end{array}$ & Jan 2011 \\
\hline $\begin{array}{l}\text { No. 1006: Public Investment and Fiscal Performance in New EU } \\
\text { Member States }\end{array}$ & Jan Hanousek and Evžen Kočenda & Dec 2010 \\
\hline No. 1005: Is Monetary Policy in New Member States Asymmetric? & Bořek Vašíček & Dec. 2010 \\
\hline $\begin{array}{l}\text { No. 1004: Inflation Targeting in Brazil, Chile \& South Africa: An } \\
\text { Empirical Investigation of Their Monetary Policy Framework }\end{array}$ & Mona Kamal & Nov. 2010 \\
\hline
\end{tabular}

